\title{
Impact of Big Data Analysis on Accounting Profession Field - Study in Jordanian Business Environment
}

\author{
Suleiman Mustafa El- Dalahmeh \\ Accounting Department, Faculty of Business School, Jerash University, Jordan \\ E-mail: dr.suliman@jpu.edu.jo
}

Received: July 10, 2020

Accepted: August 18, 2020

Published: March 11, 2021

doi: 10.5296/ijafr.v11i1.18403

URL: https://doi.org/10.5296/ijafr.v11i1.18403

\begin{abstract}
This study aims to identifying the impact of big data analysis on the accounting Profession in Jordanian business environment. To achieve the study objectives researcher distributed a questionnaire to (147) out of certified public accounts, financial analysis and experts in big data analysis in the kingdom of Jordan. (108) questionnaires were returned. The response rate was $(51.7 \%)$ of the population. In addition, the study sought to verify the hypothesis of the study. In order to analysis the data, the researcher used means, standard deviation and T-test. The result of the study revealed that the big data analysis have a significant role on the accounting roles and improve the quality of accounting characteristics in Jordan with an overall means (4.52). Based on the results of hypotheses, rejected the null basic hypothesis of the study, and the two null sub-hypotheses were rejected. In light of findings the researcher gave a number of recommendations:
\end{abstract}

1- The necessity of teaching big data and business analysis in the accounting education curricula at the undergraduate level to enhance students' knowledge of the importance of that data.

2- Holding workshops and training courses for researchers and academics to knowing them the importance of analyzing big data and how to process, store, manage and invest it in the accounting and financial field.

Keywords: Big data analysis, Accounting profession, Financial analyst, Quality of accounting information

\section{Introduction}

We deal daily with a huge amount of big data, this data represents a store of value when it becomes information, with the increasing and diversification of data, companies found themselves in front of two options, either ignoring these data or processing to benefit from it, 
to achieve a competitive advantage and increase the ability to analyze and gain new visions for companies, but this is not done by using traditional tools, therefore ignoring these data or delaying dealing with it is no longer an available option, it doesn't achieve benefit for the organizations, and has no choice but to work on acquiring data analysis and processing tools to convert it to add value.

In the past, companies suffer from a scarceness of data and information, but today there are huge quantities of big data available from many different sources, which increases the value and skills of accountants and accountancy profession.

Accountancy profession and Companies must work to benefit from that data to develop accounting and auditing standards, with a focus on analyzing data with more by way of disclosing it with the aim of providing a competitive advantage to Institution, improving accounting information, raising the efficiency of Capital markets, and helping officials and investors to make rational and accurate decisions, based on information extracted from analyzing big data (Kitchin, 2014).

So organizations that possess big data, face a great challenge of how well these Organizations are able to control, it's important that Storing and managing this data in an optimal way is a real.

The motivation of this study stems from the fact that most big data analysis studies have been conducted in developed countries, while few Studies were conducted in developing countries.

Thus, the current Study examines the impact of big data analysis on improving the quality of accounting information in the context of the developing country, Jordan.

Therefore, this study is hoped to extend our knowledge about the impact of big data analysis on the accounting profession in Jordan.

\subsection{Objectives of the Study}

The objectives of this study are:

1- To clarifying the role of big data analysis on changing the roles of accountants in the future and the accountancy profession.

2- To Conducting a field study to test the impact of big data analysis on improving the quality of characteristics of accounting information, which it reflects on improving the accounting Profession in Jordan.

\subsection{Importance of the Study}

This study derives its importance from the following considerations:

- The absence of studies in the Hashemite Kingdom of Jordan looking at the impact of big data analysis on improving accounting profession.

- The analysis of big data and its impact on Improving accounting information one of the most important topics that must be taken Care of the following up and everything 
new in this field.

\subsection{Problem of the Study}

The problem of this study is represented in the following main question: What is the impact of big data analysis on improving the quality of accounting information?

The main question is subdivided into the following sub questions:

1- Is there a statistically significant impact of big data analysis on the quality characteristics of accounting information?

2- Is there a statistically significant impact on the roles of accountants and the accounting profession in the future?

\subsection{Hypotheses of the Study}

To achieve the aims of the study, the following hypotheses have been formulated.

HO1: There is no statistically significant impact of big data analysis on the quality characteristics of accounting information.

HO2: There is no statistically significant impact of big data analysis on the roles of accountants and the accounting profession in the future.

\section{Theoretical Background}

\subsection{Big Data}

The topic of big data has received the attention of researchers in accounting thought in recent times, and the definitions provided for this term have multiplied as (Wikipedia) defined it as a collection of very large and complex data that it becomes difficult to process by using only one of the database management tools or by using application traditional data processing. It was also defined by (Gartner. Inc. 2018) specialized in information technology (IT) researches as large-scale, fast flowing and highly diversified information assets, which require economically feasible and innovative processing methods.

In order to develop insights, decision making methods and process automation, as well as the international organization for standardization (ISO 2017) defined it as a set of data sets that it has its unique characteristics such as size, speed, contrast, diversity, reliability, and validity of data, it can not be processed efficiently using traditional technology to achieve benefit from it also, (Miklos, et. al, 2015) defined it as an increasing amount of information provided by developments in computing, information technology, Internet and through previous definitions the researchers shows the increase in the amount of data is not new, but the rate of growth is unparalleled. The researcher defines big data as a set of data financial and non-financial, structured and non-structured that are obtained from internal and external sources of the organization, and time series models can be used to convert informal data into structured information useful to stakeholders and relevant to the decision-making process. 


\subsection{Types of Big Data}

A study (Rashwan 2018), (Qantajji 2014) indicated that big data can be divided into three types:

1- $\quad$ structured data: It is data in database fields, and this distinguished by the ability to search, analyze, and manage it by using the SQL Languages.

2- $\quad$ unstructured data: it is all data that can't be easily categorized as images, graphics videos, PDFs, e-mails, web pages, Facebook posts, chat messages, tweets, and others. Although, these types of files have their own internal structured, they are considered unorganized because their data are not completely consistent as database.

3- Semi- structured data: It is a mixture of the two, but it lacks unorganized structure such as Word processing programs.

\subsection{Characteristics of Big Data}

(Daniel 2018) identified the characteristics of the big data as follows:

1. Size: indicates that there are more quantities of data than in traditional methods and therefore need processors and devices capable of dealing with that data.

2. Speed: indicates that the serious data is supplied more quickly than the data in the traditional method.

Diversity: indicates that the data is more than traditional digital accounting data, but rather includes a group of other types of data, including images, sound, video and text.

3. Truthfulness: Refer to the reliability of the data as the beneficiaries care about the quality of the data, and not all data can be used in the service of institution and decision -making, so some data is eliminated.

4. Value: indicates the contribution of data in making a sound decision in a timely manner for companies. In the opinion of researcher, to take advantage of this data, we need specialists with sufficient experience and skills to deal with this data and analyze it, so that it can be considered valuable information.

\subsection{The Importance of Big Data Analysis}

Studies have shown (Georde, et al, 2018), (Zhaohao, et al, 2018), (Marijin et al, 2017), (Khaled \& Saed, 2018) (Gartner, 2014) the importance of analyzing big data in future of business is as follows:

1. provides a big competitive advantage for institutions and helps to rationalize decision making.

2. It contributes to giving a comprehensive view of the company, developing a strategy and road map for business organization, especially in customer participations, the automated process of operation and predictive analysis of decision making. In 


\section{Macrothink}

International Journal of Accounting and Financial Reporting

addition, big data analysis is used in companies to reduce operating costs.

3. Supports the preparation of integrated reports more effectively through the use of both financial and non financial information to disclose the company's performance.

4. It helps in Improving risk management, exploring opportunities to reduce costs, detect potential fraud and develop budgets.

5. It helps in increasing company profits and providing better service to clients.

6. It helps in enhancing business intelligence, identifying the most important data for business sector.

7. guiding future decisions, and enhancing the efficiency and accuracy of predictive analysis

8. Big data analysis helps companies better understand customer behavior with the aim of increasing customer satisfaction. (Kaplan, 2013) emphasized in his study the importance of using and analyzing big data in the field of auto trade, retail trade and financial services.

The researcher believes that the importance of big data does not stem from the data itself, but the value of data comes from its ability to generate a useful vision for business organization.

\section{Characteristics of the Quality of Accounting Information}

Quality of accounting information is defined as the attributes or characteristics that the accounting information contained in financial statements and reports, which enables the assessment of the level of quality of accounting information and benefit to its users in making decisions and forecasting financial failure. The characteristics of the quality of accounting information are as follows: (Abu Nassar 2018).

1- understandability feature: This feature requires financial reporting users to have a reasonable level of knowledge in accounting, economic business ,activities and have the desire to study the accounting information presented in the entity's financial reports. Also, the accounting information presented must be far from complex and difficult to understand.

2- The trait of convenience: is defined as the ability of accounting information to bring a change in the direction of the decision in a timely, and the information is appropriate when it affects the economic decisions of users and the suitability of the information is created by having predictive ability of the information and that it is of relative importance.

3- Credibility feature: Means the honest representation of accounting information, so that it can be relied upon if it is neutral, verifiable, bias-free and free from important errors and is comprehensive for the information to be reliable, the information contained in the financial reports must be within the limits of the relative importance, cost and cost.

\subsection{Comparability}

This feature enables users to make a comparison of the financial reports of the facility for 
previous periods in order to determine trends in the financial position and performance or compare the results of the facility with the results of other similar facilities for the same period.

\subsection{The Importance of Big Data on the Accounting Profession}

The impact of big data on the roles of accountants, big data and commercial analysis affect the roles of accountants in the coming years as provide an opportunity for accountants to move to strategic and effective roles in business organizations. At present time, technology is taking place in many of the functions of accountants and preparing traditional reports either in the future, a successful accountant will be an important link management between the data analyst and senior management, as well as, The actual supervisor of privacy and ethical use of big data by possessing the skills of managing and analyzing data besides his traditional role and responsibility for the integrity and quality of financial information. (Bohdan 2015) study confirmed accounting and financial professionals need to bridge the gap between the information technology department that manage tools, data, and business that need a vision to improve operations and product development. The researcher believes that the candidate for the new jobs from accountants and financialists who have technical skills and statistical skills to manage and analyze big data will definitely get higher salaries in business organization. Therefore, accountants must be aware of the importance of big data by developing their skills and increasing their ability to interpret and analyze that data with the aim of improving the quality of accounting information and adding value to business organizations. The International Accounting Accreditation (IAA) NO 7, entitled "Information Technology Skills and Knowledge for accounting Graduates" that accounting programs must include learning experiences that develop skills and knowledge related to the integration of information technology in accounting and business. The researcher believes that the reflection of this will be positive for the development of students studying accounting science and professional accountants.

\subsection{The Impact of Big Data on Financial Accounting}

(Carrol 2015) sees as the primary financial data when preparing financial statements. Methods for recording and analyzing that data have evolved over the past decades to accounting-based accounting systems and that there is an increase in financial data represented by additional data such as video, photos, emails and audio data, so it must be financial accountants are aware, knowledgeable, and sufficiently aware of the impact of big data on traditional accounting records and information. (Donald et al 2015) study indicated that big data includes the following:

Image and video data: Due to the presence of image and video capture devices, the visual data has become more widespread and quickly as the use of this data has become a reality for increasing accounting records such as storing photos and video, and includes workplace video to track worker productivity and inventory video to assess changes in the amount of actual time to measure productivity and determine Bottlenecks, and undoubtedly, image and video analytics provide useful statistics for business activities 


\section{MInstitute ${ }^{\text {Mank }}$}

International Journal of Accounting and Financial Reporting ISSN 2162-3082 2021, Vol. 11, No. 1

- Voice data: Voice data related to the company's activities enhances accounting records and improves the quality of financial information, audio sources include conference calls, shareholders 'and board meetings, customer calls, and internal phone calls to employees. (Mayew W. \& M. Venkatachalam, 2012a, 2012b) study revealed that analyzing voice data achieves quarterly profit gains, quality product and knowledge of customer satisfaction. The study concluded that there is a positive relationship between the signs of phonological cognitive dissonance, the possibility of declaring violations, and the existence of a moral correlation between profit conference calls and stock returns.

Text data: Text data includes non-financial documents such as emails, web pages, the number of Facebook participants and Twitter users, and data from these sources will be useful in supporting marketing, and giving early warning to customer service about product defects. (Zabihollah, 2017) study indicated that analyzing big data will affect financial accounting by influencing how data is collected, data management, financial statements are prepared and audited. Where financial accounting represents an information system for recording, storing, retrieving, summarizing, analyzing and presenting transactions and financial and economic events. Therefore, accounting information systems with big data analyzes can be a driving force for the success of organizations management, and the study showed that there are two directions for big data in financial accounting:

First: different data sources are integrated into accounting information systems.

Second: Big data may affect fair value accounting, so that big data related to the fair value of assets and liabilities, collected from various sources, can mitigate subjective assumptions in fair value estimates. (Michael 2015) study stated that big data analysis plays a vital role in analysis of extrabudgetary elements, and can affect the development of accounting practices and the way in which they are disclosed. A report entitled "Digital Darwinism of the Institute of Management Accounting IMA and the Association of Accredited Accountants" in 2013 indicated that the ten most important technologies that will reshape the accounting profession are big data, artificial intelligence and robotics, cloud computing, cyber security, electronic payment systems, virtual reality and digital service delivery and social communication. Therefore, accountants must learn new skills and use data mining tools to apply business intelligence programs. The researcher believes that these new technologies and big data are not and will not be gradual changes that are easy to digest and understand for business organizations and therefore Jordanian companies must, before using big data, work to modernize their financial accounting infrastructure.

\section{Previous Studies}

- The (vasarhelyi, 2012a) study discussed the need for accounting information systems to provide financial information that meets the aspirations of users of that information resulting from rapid changes in technology. The study discussed three main elements related to the measurement environment in accounting, the nature of software-based accounting information standards and the nature of the availability of coordinated and indicative information. 


\section{MInstitute ${ }_{\text {Min }}^{\text {Macrothink }}$}

International Journal of Accounting and Financial Reporting

ISSN 2162-3082

In the same context, the (kevin \& miklos, 2013) examined the impact of big data on potential accounting measurements, especially the possibility of providing transaction data in real time and the possibility of fragmenting financial reports, such as the presentation of financial reports on departments or products and other which may require different types of accounting standards.

(John \& William, 2015 ) examined the importance of keeping place with accounting to deal with big data and its reflection on international accounting standards, as it is possible to take advantage of the big amount of quantitative and descriptive data, and the data available from different sources to develop accounting standards so that the focus is on the data and processes that generate and analyze it instead of focusing on The offer, which adds value and importance to the accounting profession, empowering end users, and improving the efficiency of capital markets.

As the (Donald et al., 2015) study confirmed that big data has important implications for accounting where new types of data can be obtained, video, audio and text information can contribute to developing control systems, improving financial reports, enhancing transparency in various stakeholders and developing accounting standards.

The study (Paul, \& Arnold, 2015 (Miklos et al., 2015) addressed the importance of big data starting from the organized data included in the companies' resource planning systems, to structural and semi- structural data and the inclusion of unconventional data sources in the areas of accounting and auditing as well as the need to make changes to standards Accounting and auditing.

While the study of each of (Min Cao, et al., 2015), (Kyunghee et al., 2015), (Michael G., 2015), (Helen et al., 2015) focused on the importance of big auditing data and its role in developing auditing standards and evidence for audits in order to provide reliability and appropriate.

The (Fernando, 2016) emphasized the importance of accounting awareness of the role of social media via the Internet in providing big data, especially Facebook, and the importance of data analysis and interaction with it, and the emergence of new and broader markets in various economic, social and other areas, which requires the development of special accounting methods without specifying what they are Methods, not how to develop.

the (Diane \& Marcia, 2017), (Deb et al, 2017) suggested the inclusion of big data and technology in curriculum. (Frederick \& Bonnie, 2017) demanded data governance in light of the big data environment, with what it contains of sound data and other than Sound and expose the data to multiple risks in addition to the ambiguity of the role of analysts, especially with the development in the tools of analysis and contemporary technical development, which requires analyzing the data by accountants and proposing alternatives and providing recommendations that help in determining the elements of data governance. (Michela et al., 2017) aimed to determine the relationship between technological progress, social media and big data, and the accounting function, and how to include this in accounting, to take advantage of the rapid spread of millions of users worldwide. (Youssef 2018) aimed in his study to 
assess the importance of developing accounting in light of the big data environment by using a comprehensive, physical evaluation where he focused on 3 elements: developing accounting standards, developing curricula and academic decisions and the most important skills that these decisions must include and developing the quality of accounting information quality. Results have shown the importance of the big data environment in general for accounting and considered very high from the point of view of both the big data experts and Financial reporting preparers. The results at the level of each of the three evaluation elements were as follows: $60 \%$ the importance of big data in developing accounting standards, $23 \%$ the importance of big data in Curriculum and course development, and $17 \%$ for the quality of accounting information.

\subsection{Discussion of Previous Studies}

Despite the interest of researchers in various fields regarding the topic of big data during recent years and the multiplicity of efforts made by various parties interested in this topic, the accounting studies are still in their infancy, and the following is taken:

1- Most of the studies related to the subject of big data were conducted in developed countries, and very few were conducted in developing countries.

2- Most studies are concerned with the theoretical narration of the concept, importance and impact of big data on the accounting profession, due to the lack of interest in those studies of the audit aspect of the novelty of the topic on the one hand and the difficulty of application on the other hand.

3- Efforts are still weak in dealing with the topic of big data, its potential effects and importance for financial reporting authors, users and professional organizations interested in the accounting profession.

4- Although the big data benefited technology companies and those interested in quantitative methods and others in various fields, the benefit from this information is still limited in the field of accounting due to the absence of professional accounting standards to regulate the big data environment and the lack of clear rules to benefit from that data.

From the researcher's point of view, the huge information is not limited to its accountability but rather its importance extends to the business community, politics, security, government supervision and others, and therefore accounting is required in the near future to interact with the big data environment, to provide accounting information to its users, to the extent that meets their current and future needs at the appropriate time.

\section{Methodology of the Study}

\subsection{Data Collection and Resources}

Data collection sources were both primary and secondary. The secondary resources of the study data constituted some books and periodicals related to the subject matter of the study. The primary sources, on the other hand, represent the questionnaire tool that was designed according to the Likert scale, from 1-5. 


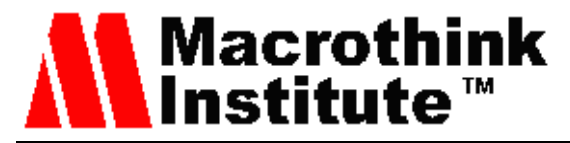

International Journal of Accounting and Financial Reporting

ISSN 2162-3082

2021, Vol. 11, No. 1

The questionnaire: When designing the questionnaire, the ideas and expressions of some previous studies were used, the most prominent of which was the study (Khalil Abdul Qadir, Proba Elham 2016), a study (Michel, 2015), a study (Kyunghye, and others 2015), a study (Wern, others) 2015), (Zabiola and Jim 2017), (Carroll, 2015), (Fay 2016), and he took into consideration the ease and clarity of the paragraphs of the questionnaire with an indication of the degree of importance, according to Likert's five-point scale which is: 5 very important, 4 important 3 medium, 2 low, 1 very low, and the questionnaire consisted of two parts:

Section one: general information.

Section Two: The impact of big data analysis on the accounting profession in Jordan and is divided into two areas:

The first field: 10 questions related to the impact of big data on the roles of accountants and the accounting profession in the future.

The second field: 10 questions related to the impact of big data on the quality of accounting information.

\subsection{Interpretation of the Results}

In order to facilitate the presentation and interpretation of results and based on the opinion of the arbitrators, arithmetic averages explain the level of impact of big data analysis on the accounting profession in Jordan as follows:

4.5 - 5 very high, 3.75 - 4.5 high, 3-3.75 medium, 2-3 low, less than 2 very low.

\subsection{Validity and Reliability of the Study Tool}

To ensure the validity of the study tool (the questionnaire) and its suitability for the goal that was set for it, it was presented to 7 arbitrators from the faculty members in the accounting departments in Jordanian universities and 12 legal auditors and 8 financial analysts, and 10 experts from the analysis of big data has been taken The researcher with their opinions and suggestions, then adjusted the questionnaire by deleting, adding and correcting it to settle on 20 paragraphs distributed in two areas. The researcher also confirmed the stability of the questionnaire by the Cronbach alpha stability factor, as its value in two areas was approximately 0.83 , and it reflects a good stability factor.

\subsection{Study Community}

The study population consists of certified accountants, financial analysts, and experts in the analysis of big data working in the 65 Jordanian industrial shareholding companies according to the shareholder guide for 2019.

\subsection{Population and Sample of the Study}

The sample of the study was a random sample of 147 respondents from certified accountants, financial analysts, and experts in analyzing big data working in the Jordanian business environment. (108) questionnaires were returned a valid for statistical researchers, the response rate was $(51.7 \%)$.

\subsection{Statistical Processing}

The researcher used the following statistical analysis:

1. Means, standard deviation, percentage, impact level and total degree. 
2. Using the T-test.

Alpha Cronbach, the Co officiant $=74.2$, which excellent compared to the acceptable rate of $60 \%$.

Table 1 . The study sample characteristics

\begin{tabular}{|c|c|c|c|c|}
\hline Variable & Variable level & No. & $\%$ & $\begin{array}{l}\text { Cumulative } \\
\text { percentage }\end{array}$ \\
\hline \multirow[t]{4}{*}{ Age } & above 40 years & 40 & $37 \%$ & $37 \%$ \\
\hline & $30-40$ years & 56 & $51.9 \%$ & $88.9 \%$ \\
\hline & Less than 30 years & 12 & $11.1 \%$ & $100 \%$ \\
\hline & Total & 108 & $100 \%$ & \\
\hline \multirow[t]{4}{*}{ Job title } & Certified Accountant & 66 & $61.1 \%$ & $61.1 \%$ \\
\hline & Financial Analyst & 28 & $25.9 \%$ & $87 \%$ \\
\hline & Big data analyst & 14 & $13 \%$ & $100 \%$ \\
\hline & Total & 108 & $100 \%$ & \\
\hline \multirow[t]{4}{*}{ Qualification } & Belcher & 84 & $77.8 \%$ & $77.8 \%$ \\
\hline & Master & 20 & $18.5 \%$ & $96.3 \%$ \\
\hline & $\mathrm{PhD}$ & 4 & $3.7 \%$ & $100 \%$ \\
\hline & Total & 108 & $100 \%$ & \\
\hline \multirow{4}{*}{ Specialization } & Accounting & 78 & $72.2 \%$ & $72.2 \%$ \\
\hline & Banking and Financial Sciences & 22 & $20.4 \%$ & $92.6 \%$ \\
\hline & Other specialties & 8 & $7.4 \%$ & $100 \%$ \\
\hline & Total & 108 & $100 \%$ & \\
\hline \multirow{4}{*}{$\begin{array}{l}\text { Years } \\
\text { Experience }\end{array}$} & Above 10 years & 62 & $57.4 \%$ & $57.4 \%$ \\
\hline & $6-10$ years & 32 & $29.6 \%$ & $87 \%$ \\
\hline & Less than 5 years & 14 & $13 \%$ & $100 \%$ \\
\hline & Total & 108 & $100 \%$ & \\
\hline
\end{tabular}




\section{MInstitute ${ }^{\text {Macrothink }}$}

International Journal of Accounting and Financial Reporting

ISSN 2162-3082

2021, Vol. 11, No. 1

Table 2. Impact of big data on accountants role and accounting profession as seen by certified public accountants

\begin{tabular}{|c|c|c|c|c|}
\hline Items & Means & S.D & $\%$ & $\begin{array}{l}\text { Impact } \\
\text { level }\end{array}$ \\
\hline Big data leads to a change in the role of the accountant in the future & 4.19 & 0.66 & $33.8 \%$ & High \\
\hline $\begin{array}{l}\text { Accountants must develop their skills and knowledge related to } \\
\text { creating data, managing, modifying, storing and analyzing data and } \\
\text { preparing reports on it and its security }\end{array}$ & 4.16 & 0.71 & $83.2 \%$ & High \\
\hline $\begin{array}{l}\text { In addition to the traditional role of the accountant, he should be an } \\
\text { effective supervisor of the privacy and ethical use of big data by } \\
\text { having the skills of managing and analyzing data. }\end{array}$ & 4.15 & 0.68 & $83 \%$ & High \\
\hline $\begin{array}{l}\text { Accountants who have technical and statistical skills to manage and } \\
\text { analyze big data will receive high and rewarding salaries in } \\
\text { economic facilities. }\end{array}$ & 4.13 & 0.82 & $82.6 \%$ & High \\
\hline $\begin{array}{l}\text { Increasing the importance of the accountant's strategic role in the } \\
\text { future by participating in making strategic decisions in economic } \\
\text { facilities. }\end{array}$ & 4.10 & 0.75 & $82 \%$ & High \\
\hline $\begin{array}{l}\text { The accountant must be sufficiently aware of the changes imposed } \\
\text { by big data such as social media, internet crime, digital services, } \\
\text { blurry computing, artificial intelligence and cloud computing. }\end{array}$ & 4 & 0.78 & $80 \%$ & High \\
\hline $\begin{array}{l}\text { Big data, represented in photos and videos, affects the traditional } \\
\text { accounting records and provides additional evidence to support } \\
\text { those records }\end{array}$ & 3.99 & 0.77 & $79.8 \%$ & High \\
\hline $\begin{array}{l}\text { Big data affects accounting by how we collect and record data, } \\
\text { manage data, and prepare and review financial statements. }\end{array}$ & 3.96 & 0.70 & $79.2 \%$ & High \\
\hline $\begin{array}{l}\text { Modern technologies are used to collect, record, analyze and display } \\
\text { information in a way that benefits the largest number of users of } \\
\text { information according to their different goals }\end{array}$ & 3.95 & 0.84 & $79 \%$ & High \\
\hline $\begin{array}{l}\text { The presence of big data will affect the way of disclosing } \\
\text { accounting information and moving from the traditional role of } \\
\text { disclosure in the financial statements to other disclosure channels } \\
\text { such as websites and social media. }\end{array}$ & 3.83 & 0.84 & $76.6 \%$ & High \\
\hline Total degree & 4.05 & 0.76 & $81 \%$ & High \\
\hline
\end{tabular}

Table 2 shows opinions of the study sample as seen by certified public accountants: Big data is changing the role of accountants in the future.

Big data, in images and video, affects traditional accounting records and provides additional evidence to support those records.

Accountants must develop skills and knowledge related to creating data, managing, modifying, storing and analyzing data, and preparing reports on it and its security. 
Big data affects accounting through how to collect and record data, manage data, and prepare and review financial statements.

Table 3. Impact of big data on accountants role and accountancy profession in the future as seen by financial analysts

\begin{tabular}{lllll}
\hline \multicolumn{1}{c}{ Items } & Mean & S.D & $\%$ & $\begin{array}{l}\text { Impact } \\
\text { level }\end{array}$ \\
\hline Big data leads to a change in the role of the accountant in the future & 4.15 & 0.65 & $83 \%$ & High \\
\hline $\begin{array}{l}\text { Accountants must develop their skills and knowledge related to } \\
\text { creating data, managing, modifying, storing and analyzing data and } \\
\text { preparing reports on it and its security }\end{array}$ & & & & \\
\hline $\begin{array}{l}\text { In addition to the traditional role of the accountant, he should be an } \\
\text { effective supervisor of the privacy and ethical use of big data by } \\
\text { having the skills of managing and analyzing data. }\end{array}$ & 0.75 & $82.2 \%$ & High \\
\hline
\end{tabular}

\begin{tabular}{|c|c|c|c|c|}
\hline $\begin{array}{l}\text { Accountants who have technical and statistical skills to manage and } \\
\text { analyze big data will receive high and rewarding salaries in } \\
\text { economic facilities. }\end{array}$ & 3.99 & 0.77 & $79.8 \%$ & High \\
\hline $\begin{array}{l}\text { Increasing the importance of the accountant's strategic role in the } \\
\text { future by participating in making strategic decisions in economic } \\
\text { facilities. }\end{array}$ & 3.96 & 0.70 & $79.2 \%$ & High \\
\hline $\begin{array}{l}\text { The accountant must be sufficiently aware of the changes imposed } \\
\text { by big data such as social media, internet crime, digital services, } \\
\text { blurry computing, artificial intelligence and cloud computing. }\end{array}$ & 3.95 & 0.84 & $79 \%$ & High \\
\hline $\begin{array}{l}\text { Big data, represented in photos and videos, affects the traditional } \\
\text { accounting records and provides additional evidence to support } \\
\text { those records }\end{array}$ & 3.90 & 0.86 & $78 \%$ & High \\
\hline
\end{tabular}

Big data affects accounting by how we collect and record data, $3.83 \quad 0.84 \quad 76.6 \% \quad$ High manage data, and prepare and review financial statements.

\begin{tabular}{|c|c|c|c|c|}
\hline $\begin{array}{l}\text { Modern technologies are used to collect, record, analyze and display } \\
\text { information in a way that benefits the largest number of users of } \\
\text { information according to their different goals }\end{array}$ & 3.80 & 1.02 & $76 \%$ & High \\
\hline $\begin{array}{l}\text { The presence of big data will affect the way of disclosing } \\
\text { accounting information and moving from the traditional role of } \\
\text { disclosure in the financial statements to other disclosure channels } \\
\text { such as websites and social media. }\end{array}$ & 3.78 & 1.90 & $75.6 \%$ & High \\
\hline Total degree & 3.96 & 0.92 & $79.2 \%$ & High \\
\hline
\end{tabular}

From Table 3, shows opinions of the study sample as seen by financial analysts:

1. Big data will change the role of accountants in the future.

2. The accountant must be sufficiently aware of the changes imposed by big data such as cloud computing, blurring computing, social media, and facing cyber crime, digital 


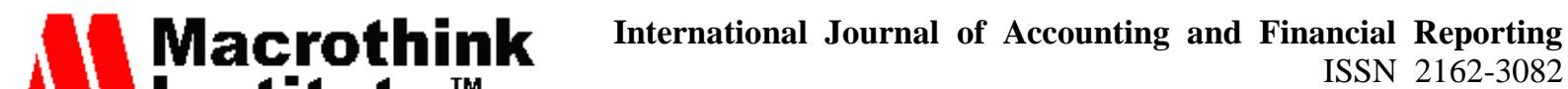 \\ 2021, Vol. 11, No. 1}

services, and artificial intelligence.

3. Modern technologies are used to collect, record, analyze and display information in a way that a large number of users benefit from the information according to their different goals.

4. The accountant must develop the skills and knowledge related to creating data, managing, modifying, storing and analyzing data and preparing reports on it and its security.

5. Big data affects accounting through how to collect and record data, manage data, and prepare and review financial statements.

Table 4. Impact of big data on accountants and accountancy profession as seen by experts of big data analysts

\begin{tabular}{|c|c|c|c|c|}
\hline Items & Mean & S.D & $\%$ & Impact level \\
\hline Big data leads to a change in the role of the accountant in the future & 4.30 & 0.82 & $86 \%$ & High \\
\hline $\begin{array}{l}\text { Accountants must develop their skills and knowledge related to } \\
\text { creating data, managing, modifying, storing and analyzing data and } \\
\text { preparing reports on it and its security }\end{array}$ & 4.28 & 0.66 & $85.6 \%$ & High \\
\hline $\begin{array}{l}\text { In addition to the traditional role of the accountant, he should be an } \\
\text { effective supervisor of the privacy and ethical use of big data by having } \\
\text { the skills of managing and analyzing data. }\end{array}$ & 4.21 & 0.64 & $84.2 \%$ & High \\
\hline $\begin{array}{l}\text { Accountants who have technical and statistical skills to manage and } \\
\text { analyze big data will receive high and rewarding salaries in economic } \\
\text { facilities. }\end{array}$ & 4.15 & 0.68 & $83 \%$ & High \\
\hline $\begin{array}{l}\text { Increasing the importance of the accountant's strategic role in the future } \\
\text { by participating in making strategic decisions in economic facilities. }\end{array}$ & 4.13 & 0.81 & $82.6 \%$ & High \\
\hline $\begin{array}{l}\text { The accountant must be sufficiently aware of the changes imposed by } \\
\text { big data such as social media, internet crime, digital services, blurry } \\
\text { computing, artificial intelligence and cloud computing. }\end{array}$ & 4.11 & 0.76 & $82.2 \%$ & High \\
\hline $\begin{array}{l}\text { Big data, represented in photos and videos, affects the traditional } \\
\text { accounting records and provides additional evidence to support those } \\
\text { records }\end{array}$ & 4.08 & 0.78 & $81.6 \%$ & High \\
\hline $\begin{array}{l}\text { Big data affects accounting by how we collect and record data, manage } \\
\text { data, and prepare and review financial statements. }\end{array}$ & 3.90 & 0.84 & $78 \%$ & High \\
\hline $\begin{array}{l}\text { Modern technologies are used to collect, record, analyze and display } \\
\text { information in a way that benefits the largest number of users of } \\
\text { information according to their different goals }\end{array}$ & 3.34 & 1.19 & $66.8 \%$ & Medium \\
\hline $\begin{array}{l}\text { The presence of big data will affect the way of disclosing accounting } \\
\text { information and moving from the traditional role of disclosure in the } \\
\text { financial statements to other disclosure channels such as websites and } \\
\text { social media. }\end{array}$ & 3.3 & 1.12 & $66 \%$ & Medium \\
\hline Total degree & 3.98 & 0.83 & $79.6 \%$ & High \\
\hline
\end{tabular}




\section{MInstitute ${ }^{\text {Macrothink }}$}

International Journal of Accounting and Financial Reporting

ISSN 2162-3082

2021, Vol. 11, No. 1

From Table 4, shows the opinions of the study sample as seen by experts of big data analysis, as follows:

1. The accountant must develop the skills and knowledge related to creating data, managing, modifying, storing and analyzing data and preparing reports on it and its security.

2. Increasing the importance of the accountant's strategic role in the future by participating in making strategic decisions in economic facilities

3. The accountant must be sufficiently aware of the changes imposed by big data such as cloud computing, blurring computing, social media, and facing cyber crime, digital services, and artificial intelligence

4. Modern technologies are used to collect, record, analyze and display information in a way that a large number of users benefit from the information according to their different goals.

Big data affects accounting through how to collect and record data, manage data, and prepare and review financial statements

Based on the above: there is impact of the big data on the roles of accountants and the accounting profession in the future. So, this leading to rejection of the null hypothesis and acceptance of alternative hypothesis which states that "there is impact of the big data on the roles of accountants and the accounting profession in the future."

Table 5. Impact of big data on the characteristics of the quality of accounting information as seen by certified public accountants

\begin{tabular}{|c|c|c|c|c|}
\hline Items & Mean & S.D & $\%$ & $\begin{array}{l}\text { Impact } \\
\text { level }\end{array}$ \\
\hline $\begin{array}{l}\text { Big data analysis provides relevant, objective and valuable information } \\
\text { that helps in making decisions about the economic establishment. }\end{array}$ & 4.27 & 0.69 & $85.4 \%$ & High \\
\hline $\begin{array}{l}\text { Big data analysis improves understanding and analysis of accounting } \\
\text { information content. }\end{array}$ & 4.18 & 0.75 & $83.6 \%$ & High \\
\hline $\begin{array}{l}\text { Big data analysis improves the understanding of annual financial } \\
\text { reports by providing detailed data on the economic unit through } \\
\text { discussions, calls and videos, which increases the reliability and quality } \\
\text { of accounting information }\end{array}$ & 3.61 & 0.82 & $72.2 \%$ & Medium \\
\hline $\begin{array}{l}\text { Big data analysis improves an understanding of the nature of different } \\
\text { processes in an economic unit and an improved understanding of the } \\
\text { strategic performance of an economic unit as a whole. }\end{array}$ & 4.23 & 0.70 & $84.6 \%$ & High \\
\hline $\begin{array}{l}\text { Big data analysis improves forecasting of profits and future risks, which } \\
\text { increases the reliability and quality of accounting information. }\end{array}$ & 3.65 & 0.81 & $73 \%$ & Medium \\
\hline $\begin{array}{l}\text { Big data analysis improves future growth opportunities and improves } \\
\text { forecasting of future performance of economic units }\end{array}$ & 3.62 & 0.75 & $72.4 \%$ & Medium \\
\hline
\end{tabular}




\section{Macrothink}

International Journal of Accounting and Financial Reporting

ISSN 2162-3082

2021, Vol. 11, No. 1

Big data analysis improves the evaluation of the company's $4.19 \quad 0.76 \quad 83.8 \%$ High performance, which increases the degree of confidence in accounting information.

The analysis of big data leads to providing more information to $4.04 \quad 0.73 \quad 80.8 \% \quad$ High stakeholders, which leads to improving the quality of accounting information and thus reducing information asymmetry

\begin{tabular}{llllll}
\hline Big data analysis improves the comparability of information between & 4.03 & 0.73 & $80.6 \%$ & High
\end{tabular} sectors of the economic unit or between a specific sector and its market counterpart

Big data analysis improves the comparability of information between

4.20 $0.8584 \%$

High sectors of the economic unit or between a specific sector and its market counterpart.

Table 5 shows the most important elements according to the criterion of relative importance as seen by certified public accountants are as follows:

1- Big data analysis provides relevant, objective and valuable information that helps in making decisions about the economic establishment.

2- Big data analysis improves understanding and analysis of accounting information content.

3- Big data analysis improves an understanding of the nature of different processes in an economic unit and an improved understanding of the strategic performance of an economic unit as a whole.

4- Big data analysis improves the evaluation of the company's performance, which increases the degree of confidence in accounting information.

5- The analysis of big data leads to providing more information to stakeholders, which leads to improving the quality of accounting information and thus reducing information asymmetry.

6- Big data analysis improves the comparability of information between sectors of the economic unit or between a specific sector and its market counterpart.

7- Big data analysis improves the comparability of information between sectors of the economic unit or between a specific sector and its market counterpart.

Table 6. Impact of big data on the characteristics of the quality of accounting information as seen by financial analysts 


\section{Macrothink}

International Journal of Accounting and Financial Reporting

ISSN 2162-3082

2021, Vol. 11, No. 1

\begin{tabular}{llllll}
\hline Big data analysis provides relevant, objective and valuable information that & 3.93 & 0.73 & $78.5 \%$ & High
\end{tabular}

helps in making decisions about the economic establishment.

\begin{tabular}{|c|c|c|c|c|}
\hline $\begin{array}{l}\text { Big data analysis improves understanding and analysis of accounting } \\
\text { information content. }\end{array}$ & 3.73 & 0.82 & $67.46 \%$ & Medium \\
\hline $\begin{array}{l}\text { Big data analysis improves the understanding of annual financial reports by } \\
\text { providing detailed data on the economic unit through discussions, calls and } \\
\text { videos, which increases the reliability and quality of accounting information }\end{array}$ & 4.09 & 0.76 & $81.80 \%$ & High \\
\hline $\begin{array}{l}\text { Big data analysis improves an understanding of the nature of different } \\
\text { processes in an economic unit and an improved understanding of the } \\
\text { strategic performance of an economic unit as a whole. }\end{array}$ & 4.01 & 0.58 & $80.2 \%$ & High \\
\hline $\begin{array}{l}\text { Big data analysis improves forecasting of profits and future risks, which } \\
\text { increases the reliability and quality of accounting information. }\end{array}$ & 3.98 & 0.94 & $79.6 \%$ & High \\
\hline $\begin{array}{l}\text { Big data analysis improves future growth opportunities and improves } \\
\text { forecasting of future performance of economic units }\end{array}$ & 4.12 & 0.57 & $82.4 \%$ & High \\
\hline $\begin{array}{l}\text { Big data analysis improves the evaluation of the company's performance, } \\
\text { which increases the degree of confidence in accounting information. }\end{array}$ & 3.95 & 0.80 & $79 \%$ & High \\
\hline $\begin{array}{l}\text { The analysis of big data leads to providing more information to } \\
\text { stakeholders, which leads to improving the quality of accounting } \\
\text { information and thus reducing information asymmetry }\end{array}$ & 4.13 & 0.84 & $82.6 \%$ & High \\
\hline $\begin{array}{l}\text { Big data analysis improves the comparability of information between sectors } \\
\text { of the economic unit or between a specific sector and its market counterpart }\end{array}$ & 4.27 & 0.71 & $85.4 \%$ & High \\
\hline $\begin{array}{l}\text { Big data analysis improves the comparability of information between sectors } \\
\text { of the economic unit or between a specific sector and its market counterpart. }\end{array}$ & 3.98 & 0.87 & $80.3 \%$ & High \\
\hline Total degree & 4.013 & 0.48 & $80 \%$ & High \\
\hline
\end{tabular}

Table 6 shows the most important elements according to the criterion of relative importance as seen by the financial analysts:

1- Big data analysis improves the understanding of annual financial reports by providing detailed data on the economic unit through discussions, calls and videos, which increases the reliability and quality of accounting information

2- Big data analysis improves an understanding of the nature of different processes in an economic unit and an improved understanding of the strategic performance of an economic unit as a whole.

3- Big data analysis improves future growth opportunities and improves forecasting of future performance of economic units.

4- The analysis of big data leads to providing more information to stakeholders, which leads to improving the quality of accounting information and thus reducing information asymmetry.

Big data analysis improves the comparability of information between sectors of the economic unit or between a specific sector and its market counterpart. 


\section{I Macrothink}

International Journal of Accounting and Financial Reporting

ISSN 2162-3082

2021, Vol. 11, No. 1

Table 7. Impact of big data on the characteristics of quality of accounting information as seen by experts of big data analysts

\begin{tabular}{|c|c|c|c|c|}
\hline Items & Mean & S.D & $\%$ & $\begin{array}{l}\text { Impact } \\
\text { level }\end{array}$ \\
\hline $\begin{array}{l}\text { Big data analysis provides relevant, objective and valuable information that helps } \\
\text { in making decisions about the economic establishment. }\end{array}$ & 3.94 & 0.73 & $78.8 \%$ & High \\
\hline $\begin{array}{l}\text { Big data analysis improves understanding and analysis of accounting information } \\
\text { content. }\end{array}$ & 4.08 & 0.62 & $81.6 \%$ & High \\
\hline $\begin{array}{l}\text { Big data analysis improves the understanding of annual financial reports by } \\
\text { providing detailed data on the economic unit through discussions, calls and } \\
\text { videos, which increases the reliability and quality of accounting information }\end{array}$ & 3.76 & 0.76 & $75.2 \%$ & High \\
\hline $\begin{array}{l}\text { Big data analysis improves an understanding of the nature of different processes } \\
\text { in an economic unit and an improved understanding of the strategic performance } \\
\text { of an economic unit as a whole. }\end{array}$ & 4.04 & 0.81 & $80.8 \%$ & High \\
\hline $\begin{array}{l}\text { Big data analysis improves forecasting of profits and future risks, which increases } \\
\text { the reliability and quality of accounting information. }\end{array}$ & 4.29 & 0.48 & $85.8 \%$ & High \\
\hline $\begin{array}{l}\text { Big data analysis improves future growth opportunities and improves forecasting } \\
\text { of future performance of economic units }\end{array}$ & 4.26 & 0.69 & $85.2 \%$ & High \\
\hline $\begin{array}{l}\text { Big data analysis improves the evaluation of the company's performance, which } \\
\text { increases the degree of confidence in accounting information. }\end{array}$ & 4.18 & 0.75 & $83.6 \%$ & High \\
\hline $\begin{array}{l}\text { The analysis of big data leads to providing more information to stakeholders, } \\
\text { which leads to improving the quality of accounting information and thus reducing } \\
\text { information asymmetry }\end{array}$ & 4.26 & 0.72 & $85.2 \%$ & High \\
\hline $\begin{array}{l}\text { Big data analysis improves the comparability of information between sectors of } \\
\text { the economic unit or between a specific sector and its market counterpart }\end{array}$ & 4.22 & 0.72 & $84.4 \%$ & High \\
\hline $\begin{array}{l}\text { Big data analysis improves the comparability of information between sectors of } \\
\text { the economic unit or between a specific sector and its market counterpart. }\end{array}$ & 4.16 & 0.86 & $82.2 \%$ & High \\
\hline Total degree & 4.12 & 0.47 & $82.4 \%$ & High \\
\hline
\end{tabular}

Table 7 shows the most important elements according to the criterion of relative importance as seen by financial analysts are as follows:

1- Big data analysis improves understanding and analysis of accounting information content.

2- Big data analysis improves an understanding of the nature of different processes in an economic unit and an improved understanding of the strategic performance of an economic unit as a whole.

3- Big data analysis improves forecasting of profits and future risks, which increases the reliability and quality of accounting information. 
4- Big data analysis improves future growth opportunities and improves forecasting of future performance of economic units.

5- Big data analysis improves the evaluation of the company's performance, which increases the degree of confidence in accounting information.

6- The analysis of big data leads to providing more information to stakeholders, which leads to improving the quality of accounting information and thus reducing information asymmetry.

7- Big data analysis improves the comparability of information between sectors of the economic unit or between a specific sector and its market counterpart.

8- Big data analysis improves the comparability of information between sectors of the economic unit or between a specific sector and its market counterpart.

\section{Hypotheses test:}

To test the basic hypothesis of the study, use the multiple regression method and it was based on the value of $\mathrm{T}$. The decision rule was to reject the null hypothesis and accept the alternative hypothesis if the calculated value of $\mathrm{T}$ is greater than the tabular at a significance index of 0.05 which corresponds to a confidence level of $95 \%$.

Test the basic hypothesis of the study:

HO: There is no impact of big data analysis on improving the quality of accounting information.

Ha: There is impact of big data analysis on improving the quality of accounting information.

Table 8

\begin{tabular}{lllll}
\hline hypothesis & T- calculated & T -tabular & $\begin{array}{l}\text { Significance } \\
\text { level }\end{array}$ & Allowable error \\
\hline $\begin{array}{l}\text { Main } \\
\text { hypothesis }\end{array}$ & 7.712 & 1.645 & 0.000 & 0.05 \\
\hline
\end{tabular}

Result of the first sub-hypothesis test:

Table 9 shows the result of testing the first null sub-hypothesis.

HO1: There is no statistically significant effect of big data analysis on the quality characteristics of accounting information.

Table 9

\begin{tabular}{lllll}
\hline hypothesis & T- calculated & T -tabular & $\begin{array}{l}\text { Significanc } \\
\text { e level }\end{array}$ & Allowable error \\
\hline $\begin{array}{l}\text { First null Sub- } \\
\text { hypothesis }\end{array}$ & 2.773 & 1.645 & 0.032 & 0.05 \\
\hline
\end{tabular}




\section{MIN Macrothink}

International Journal of Accounting and Financial Reporting

ISSN 2162-3082

2021, Vol. 11, No. 1

Table 9 shows the result of the first null hypothesis test, from which it is clear that the value of the calculated and extracted $\mathrm{T}$ from computer results 2.773 and this value is statistically significant at the level of significance (0.006), that is, it indicates a level of confidence (0.994), including That this level is greater than the level of confidence approved in the study, which is $95 \%$, the researcher rejects the null hypothesis and accepts the alternative hypothesis which states:

Ha1: There is statistically significant effect of big data analysis on the quality characteristics of accounting information.

Result of the second sub-hypothesis test:

Table 10 shows the result of testing the second null sub-hypothesis.

HO2: There is no statistically significant effect on the roles of accountants and the accounting profession in the future.

Table 10

\begin{tabular}{lllll}
\hline hypothesis & T- calculated & T -tabular & $\begin{array}{l}\text { Significance } \\
\text { level }\end{array}$ & Allowable error \\
\hline $\begin{array}{l}\text { Second null } \\
\text { Sub-hypothesis }\end{array}$ & 2.180 & $1 . .645$ & 0.038 & 0.05 \\
\hline
\end{tabular}

Table 10 shows the results of the second nutritional hypothesis test, as the calculated $\mathrm{T}$ value equals 2.180 and it is greater than the value of the tabular numeral 1.645, the decision rule is to reject the null hypothesis and accept the alternative hypothesis if the calculated $\mathrm{T}$ value is greater than the tabular value. Accordingly, the researcher rejects the second null hypothesis and accepts the alternative hypothesis which states:

Ha2: There is statistically significant effect on the roles of accountants and the accounting profession in the future.

\section{Conclusion}

The result of the study as seen by certified public accountants, financial analysts and experts in big data showed that big data will change the role of accountants in the future and will affect on the accountancy profession. Also the study revealed that business organization achieve many advantages, when they analyze the big data, including contributing to giving a comprehensive view of economic establishment, increasing understanding of its activities, developing its strategy, achieving a high competitive advantages for institutions and providing relevant information that helps in rationalizing decisions within the economic unit, and it is a source of future information that affects the decisions of owners interests, in addition improving the quality of accounting information, therefore, accountants must be aware of the opportunities and risks related to big data on a successful accountant in the future, will need analytical and information management skills to play the mediating role between the data analyst and senior management. It is fair to conclude that accountant have been widely affected by the use of technology in business arena. As the business environment changes, the role of the accountants changes as well. Based on the results of hypotheses tested, the two null hypotheses of the study were rejected. The results of study consistent with the 
results of previous studies such as those conducted by the (John \& William, 2015), (Carrol, 2015), (Donald et al. 2015), (Fernando, 2016), (Michela et al, 2017) (Zabihollah 2017) (Drane \& Marcia, 2017) (Youssef, 2018).

In the light of the findings, the researcher gave a number of recommendations:

1. Accounting students need to be prepared to acquire technological know - how.

2. Students will not only need to posses general accounting skills but also, general computer knowledge and statistics .

3. Anyone planning to go into the accounting field would have to be able to adopt well to technology because technology is dramatically impacting this field.

Teachers should ensure that the accounting courses that student are required to take include the computer skills that will make accounting graduates desirable to industry in light of big data environment.

\section{References}

Abu Nassar, M. (2018). International Financial Accounting and Reporting Standards.

Alles, M. G. (2015). Drivers of the use and facilitators and obstacles of the evolution of big data by the audit profession. Accounting Horizons, 29(2), 439-449.

Arnaboldi, M., Busco, C., \& Cuganesan, S. (2017). Accounting, accountability, social media and big data: revolution or hype?. Accounting, Auditing \& Accountability Journal, 30(4), 762-776.

Brown-Liburd, H., Issa, H., \& Lombardi, D. (2015, June). Behavioral Implications of Big Data's Impact on Audit Judgment and Decision Making and Future Research Directions. Accounting Horizons, 29(2), 451- 468.

Cao, M., Chychyla, R., \& Stewart, T. (2015, June). Big Data Analytics in Financial Statement Audits. Accounting Horizons, 29(2), 423-430.

Encyclopedia Wikipedia. Retrieved from http://www.wikipedia.org

Fernando, $\mathrm{N}$ van der Vlist. (2016, June). Accounting for the social: Investigating commensuration and Big Data practices at Facebook. Big Data \& Society, 1-16.

Gartner Inc. (2014). Strategic CPM as a driver for organizational performance management. Retrieved October 13, 2017, from https://www.gartner.com

Gartner Inc. (2018). "Big Data". Retrieved March 18, 2018, from https://www.gartner.com/glossary/big-data

Gashi, K., \& Al-Awadi, S. (2018). Big Data and its Impact on Decision-Making. Journal of Economics and Applied Statistics, 14(2), 150-165.

Griffin, P. A., \& Arnold, M. (2015, June). Commentaries on Big Data's Importance for Accounting and Auditing. Accounting Horizons, 29(2), 409-422. 


\section{MInstitute Macrothink $_{\text {Int }}$}

International Journal of Accounting and Financial Reporting ISSN 2162-3082

International Organization for Standardization (ISO/IEC). (2017). "Big Data". Retrieved from www.iso.org

Janssen, M., Voort, H., \& Wahyudi, A. (2017). Factors influencing big data decision making quality. Journal of Business Research, (70), 338-345.

Janvrin, D. J., \& Marcia, W. W. (2017). "Big Data": A new twist to accounting. Journal of Accounting Education, (38), 3-8.

Kaplan. (2013). Analyzing big data: the path to competitive advantage. Retrieved October 28, 2017, from http://hosteddocs.ittoolbox.com

Kitchin, R. (2014). The Data Revolution: Big Data, Open Data. Data Infrastructures \& Their Consequences. London: SAGE Publications.

Krahel, J. P., \& Titera, W. R. (2015, June). Consequences of Big Data and Formalization on Accounting and Auditing Standards. Accounting Horizons, 29(2), 377-380.

Mayew, W., \& Venkatachalam, M. (2012a). Analyzing speech to detect financial misreporting. Journal of Accounting Research, 500(2), 349-392.

Mayew, W., \& Venkatachalam, M. (2012b). The power of voice: Managerial affective states and future firm performance. The Journal of Finance, 67(1), 1-43.

McKnight, C. (2015). Preliminary Investigation of Big Data and Implications for Accounting Curricula (pp. 1-11). Retrieved from https://unitec.researchbank.ac.nz

Moffitt. K., \& Vasarhelyi, M. A. (2013). AIS in an Age of Big Data. Journal of Information Systems, 27(2), 1-19.

O’Leary, D. E. (2018). Big Data and Knowledge Management with Applications in Accounting and Auditing: The Case of Watson. Retrieved July 9, from https://ssrn.com/abstract=3203842

Qantajji. (2014, December). The Big Data Market and New Concepts. World Islamic Economy Magazine, 1-4.

Rashwan. (2018). The Role of Big Data Analysis in Rationalizing Financial and Administrative Decision Making in Palestinian Universities - A Field Study. Journal of Economic and Financial Studies, 11(1), 22-41.

Rezaee, Z., \& Wang, J. (2017, October). Big Data, Big Impact on Accounting. APLUS, 42-45.

Salijeni, G. M., Samsonova, A., \& Turley, S. (2018). Big Data and changes in Audit Technology: Contemplating a Research Agenda. Accounting and Business Research, 1-26.

Sledgianowski, D., Gomaa, M., \& Tan, C. (2017). Toward integration of Big Data, technology and information systems competencies into the accounting curriculum. Journal of Accounting Education, (38), 81-93. 


\section{Macrothink}

International Journal of Accounting and Financial Reporting ISSN 2162-3082

Stryk, B. (2015). How do Organizations Prepare and Clean Big Data to Achieve Better Data Governance?. Capella University, ProQuest Dissertations Publishing 3682586.

Sun, Z., Sun, L. L., \& Strang, K. (2018). Big Data Analytics Services for Enhancing Business Intelligence. Journal of Computer Information Systems, 58(2), 162-169.

The International Accounting Accreditation (IAA) NO 7. Information Technology Skills and Knowledge for accounting Graduates.

Vasarhelyi, M. A. (2012a). AIS in a more rapidly evolving era. Journal of Information Systems, Spring.

Vasarhelyi, M. A., Kogan, A., \& Tuttle, B. M. (2015). Big data in accounting: an overview. Accounting Horizons, 29(2), 381-396.

Warren, D., Moffitt, K., \& Byrnes, P. (2015, June). How Big Data Will Change Accounting. Accounting Horizons, 29(2), 397-407.

Yoon, K., Hoogduin, L., \& Zhang, L. (2015, June). Big Data as Complementary Audit Evidence. Accounting Horizons, 29(2), 431-438.

Youssef, J. (2018). A Proposed Introduction to Evaluating the Importance of Accounting Development in the Big Data Environment. Journal of Accounting Thought, 22(4), 1225-1272.

\section{Copyright Disclaimer}

Copyright for this article is retained by the author(s), with first publication rights granted to the journal.

This is an open-access article distributed under the terms and conditions of the Creative Commons Attribution license (http://creativecommons.org/licenses/by/4.0/) 